\section{Selection of Cape Gooseberry Based on Physical Variables of Their Fruit}

\author{
Job Teixeira de Oliveira \\ Department of Agronomy, Universidade Federal do Mato Grosso do Sul, \\ Chapadão do Sul, Brazil
}

\author{
Fernando França da Cunha, Rubens Alves de Oliveira, and \\ Catariny Cabral Aleman Pina \\ Department of Agricultural Engineering, Universidade Federal de Viçosa, \\ Viçosa-MG, Brazil
}

Additional index words. fruit growing, fruitful, path analysis, Solanaceae

\begin{abstract}
Path coefficient analysis has been widely used to understand production better and determine the relationships between fruit and their constituents. This study evaluated the correlations between mass and other physical characteristics, and contributes to selecting cape gooseberry fruit. The attributes assessed were the total mass of the cape gooseberry fruit (TM) (fruit mass with husk), fruit mass (FM) (fruit mass without husk), husk mass (HM), husk length (HL), the largest transverse husk diameter (LD), fruit diameter (FD), and color of the husk (CH). Using path analysis, it was possible to verify directly that, among the physical components of the study, TM and FD have a direct and positive influence on FM. Fruit mass had a direct and negative correlation with HM, indicating that fruit with the heaviest husk (and green color) have not yet reached full maturation, nor reached their greatest mass. This result suggests that TM is strongly indirectly influenced by the HL, husk diameter, HM, and FD.
\end{abstract}

Cape gooseberry (Physalis peruviana) is a climacteric fruit with a fleshy berry type covered by a husk or calyx that prolongs the postharvest shelf life by two thirds more than fruit without husk by decreasing respiratory intensity and reducing weight loss (Bolzan et al., 2011). Such features have resulted in an increasing demand by the consumer market (Santana et al., 2020).

This species belongs to the Solanaceae family. Most of the management (support for the plant, fertilization, weed control, and irrigation) is similar to that used for growing tomatoes (Solanum lycopersicum). The plant is considered shrubby, perennial, and rustic, reaching up to $2 \mathrm{~m}$ in height. The leaves are velvety and triangular, whereas the main stem is herbaceous and hairy, and has 8 to 12 nodes. The fruit is fleshy and sphere-shaped, and each plant can produce $\approx 2 \mathrm{~kg}$ of fruit during the entire harvest period (Lima et al., 2009).

Path coefficient analysis or path analysis has been widely used to understand fruit yield better and to determine the nature of the relationships between fruit and their constituent components. This coefficient helps to identify the impacts on fruit mass and can be used as selection criteria. Therefore, path analysis is a multivariate method that can be used to

Received for publication 1 Dec. 2021. Accepted for publication 13 Jan. 2022.

Published online 11 February 2022.

J.T.O. is the corresponding author. E-mail: job. oliveira@hotmail.com.

This is an open access article distributed under the CC BY-NC-ND license (https://creativecommons. org/licenses/by-nc-nd/4.0/). understand and estimate how the correlations of physical variables of fruit affect their mass (Abadi et al., 2021; Oliveira et al., 2021).

We report the results of our study that aimed to select and evaluate correlations between the mass and other physical characteristics of cape gooseberry fruit, indicating direct and indirect effects of the morphology and physical traits on cape gooseberry fruit.

\section{Material and Methods}

The study was carried out in Bicas, Minas Gerais, Brazil, at $23 \mathrm{~K}, 700832.61 \mathrm{~m} \mathrm{E}$; $7596335.29 \mathrm{~m} \mathrm{~S}$ (UTM). According to the Köppen and Geiger classification, the climate of the region is characterized as Cwa-type. During the study year, the temperature ranged from 13 to $30^{\circ} \mathrm{C}$, and the average annual rainfall was $1232 \mathrm{~mm}$.

This research was conducted using 4510 month-old plants in an inverted-V support system, spaced 1.0 and $0.5 \mathrm{~m}$ between lines and plants, respectively, and $3.5 \mathrm{~m}$ between rows.

The fruit were harvested manually to avoid any influence or physical damage, which establishes that they must be homogeneous in quality, classifying them by size, shape, color, and should not be harvested moist or super matured. After harvesting, 100 random fruit from different plants were selected, excluding those that showed defects, to avoid any undesirable influence that could hinder or interfere with the research results.

The physical attributes evaluated were TM expressed in grams, which was obtained using a scale with precision $0.1 \mathrm{~g}$; FM expressed in grams; and HM expressed in grams. HL, LD, and FD, expressed in millimeters, were obtained using $0.01-\mathrm{mm}$ precision digital caliper.

Harvest was carried out according to the different $\mathrm{CH}$, with four stages of harvest recorded as 1 point, green-yellowish; 2 points, greenish yellow; 3 points, yellow; and 4 points, yellow-brown, following the methodology of Lima et al. (2009).

A path analysis was run using the methodology described by Cruz (2013), who states that ignoring the effects of multicollinearity can cause the wrong results. For this, multicollinearity diagnoses must be made to make sure studies are feasible. In this sense, the degree of multicollinearity of the matrix $\mathrm{X}^{\prime} \mathrm{X}$ was established based on its condition number $(\mathrm{CN})$, which is the ratio between the highest and lowest eigenvalue of the matrix (Montgomery et al., 2012). If $\mathrm{CN}>1000$, multicollinearity is considered severe; if $100 \leq$ $\mathrm{CN} \leq 1000$, multicollinearity is considered moderate to strong; and if $\mathrm{CN}<100$, multicollinearity is considered weak and is not a problem for the analysis. All statistical analyses were performed using GENES software (Version 2; Viçosa, MG, Brazil) (Cruz, 2013).

\section{Results and Discussion}

According to the $\mathrm{CN}$ criterion presented by Montgomery et al. (2012), the Pearson correlation estimation matrix obtained here presented a weak degree of multicollinearity with a $\mathrm{CN}$ of 75 . Therefore, ridge regression analysis was performed to correct the multicollinearity. Figure 1 shows the Pearson correlation network, where the green lines represent positive correlations and the red lines indicate negative correlations. Line thickness indicates a greater degree of correlation. It is noteworthy that the $\mathrm{FM} \times \mathrm{TM}$, $\mathrm{TM} \times \mathrm{FD}, \mathrm{FD} \times \mathrm{FM}$, and $\mathrm{HL} \times \mathrm{LD}$ correlations were significant and positive. The $\mathrm{CH} \times$ HM correlation was significant and negative. This result suggests that the lower the moisture

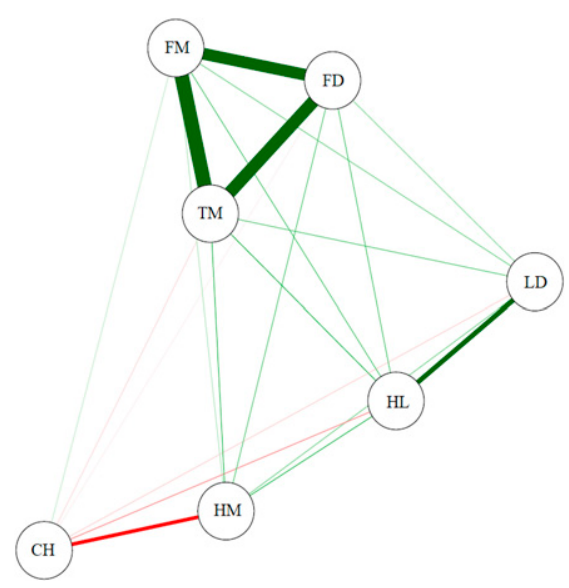

Fig. 1. Correlation network referring to the study variables: fruit mass without husk (FM), the total mass of the cape gooseberry fruit (TM), husk mass (HM), husk length (HL), the largest husk diameter (LD), fruit diameter (FD), and color of the husk $(\mathrm{CH})$. 


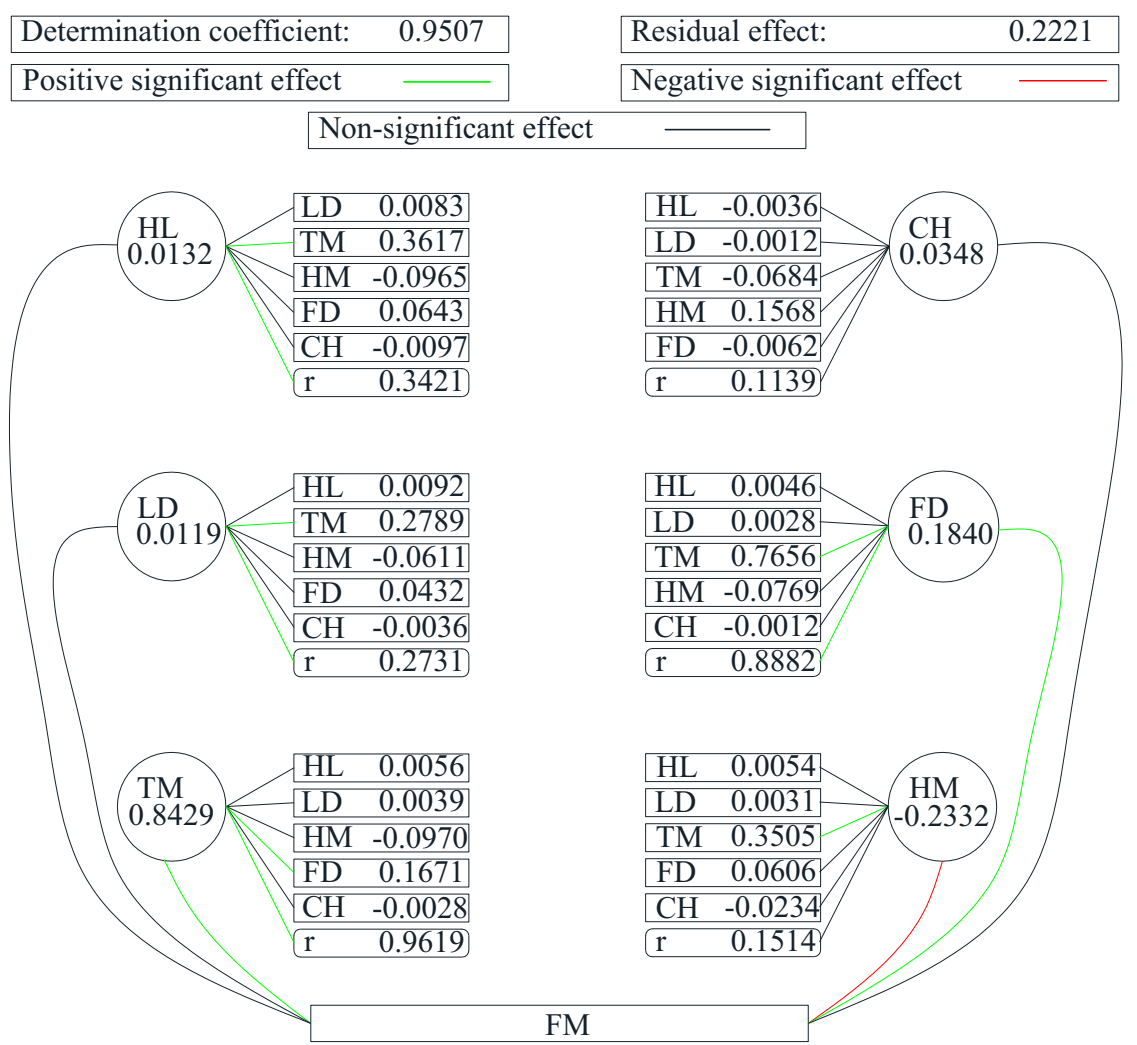

Fig. 2. Path analysis among the fruit mass without husk (FM), the total mass of the cape gooseberry fruit (TM), husk mass (HM), husk length (HL), the largest husk diameter (LD), fruit diameter (FD), and color of the husk $(\mathrm{CH})$.

(the drier) of the husk, the browner the color and the lower the husk mass. Santana et al. (2020) observed that fruit mass variables with and without husk correlate positively. They emphasize that this occurs because the values of both have a slight difference. Others report that the husk of cape gooseberry fruit contributes to the increase in fruit mass (Fischer and Lüdders, 1997; Fischer et al., 2015).

We present our results in Fig. 2 using a scheme in which it is possible to verify the variables that obtained the greatest positive direct effects on FM, which were TM and FD, with correlation coefficient values of 0.8429 , and 0.1840 respectively. Considering that a variable is viable for the direct selection of larger and more attractive fruit, it must have a direct effect and a high correlation in the same direction as the main variable (Oliveira et al., 2021).

FM had a negative correlation with HM. As verified previously in the correlation network shown in Fig. 1, heavier husks (green) are those that have not yet acquired full maturation, and the fruit have not reached their greatest mass, indicating that brown husks are the most suitable for commercialization because of their greater FM. The presence of the husk in fruit of the Physalis genus protects the fruit from attack by insects, birds, pathogens, and adverse environmental conditions during cultivation, and prolongs postharvest shelf life compared with fruit without a husk (Bolzan et al., 2011).

As shown in Fig. 2, HL, husk diameter, $\mathrm{HM}$, and FD have a strong and indirect influence on TM of the cape gooseberry fruit.

In our study, a coefficient of determination of 0.9507 was found. This value is considered high, as described by Oliveira et al. (2021). It is noteworthy that new studies can be implemented to improve production and management, and to add economic value to the cape gooseberry.

\section{Conclusion}

Path analysis enabled us to verify that, among the physical components of the study, TM and FD have a direct and positive influence on FM of the cape gooseberry without husk. FM correlated directly with HM, indicating that fruit with the heaviest husk (green) have not yet reached full maturation and acquired their greatest mass. This result also suggests indirectly that TM of cape gooseberry is strongly influenced by HL, husk diameter, HM, and FD.

\section{Literature Cited}

Abadi, B., S. Mahdavian, and F. Fattahi. 2021. The waste management of fruit and vegetable in wholesale markets: Intention and behavior analysis using path analysis. J. Clean. Prod. 279:1-13, https://doi.org/10.1016/j.jclepro.2020.123802.

Bolzan, R.P., F.L. Cuquel, and O.J. Lavoranti. 2011. Armazenamento refrigerado de Physalis. Rev. Bras. Frutic. 33:577-583, https://doi.org/ 10.1590/S0100-29452011000500079.

Cruz, C.D. 2013. Genes: A software package for analysis in experimental statistics and quantitative genetics. Acta Sci. Agron. 35:271-276, https://doi.org/10.4025/actasciagron.v35i3.21251.

Fischer, G. and P. Lüdders. 1997. Alterações de desenvolvimento de carboidratos em frutos de groselha-do-cabo (Physalis peruviana L.) em relação ao cálice e às folhas. Agron. Colomb. 14:95-107, https://bibliotecas.unal.edu.co/servicios/ biblioteca-digital.

Fischer, G., C. Ulrichs, and G. Ebert. 2015. Contents of non-structural carbohydrates in the fruiting cape gooseberry (Physalis peruviana L.) plant. Agron. Colomb. 33(2):155-163, https://doi.org/10.15446/agron.colomb.v33n2. 515462.

Lima, C.S.M., J. Severo, R. Manica-Berto, J.A. Silva, L. Rufato, and A.D.R. Rufato. 2009. Características físico-químicas de Physalis em diferentes colorações do cálice e sistemas de condução. Rev. Bras. Frutic. 31:1061-1068, https://doi.org/10.1590/ S0100-29452009000400020.

Montgomery, D.C., E.A. Peck, and G.G. Vining. 2012. Vining: Introduction to linear regression analysis. 5th ed. Wiley, New York, NY.

Oliveira, J.T., R.A. Oliveira, P.A. Silva, and P.E. Teodoro. 2021. Contribution to the selection of blackberry through fruit physical variables. HortScience 56:1003-1004, https://doi.org/ 10.21273/HORTSCI15913-21.

Santana, A.S., C.L. Giacobbo, J. Prado, A. Uberti, B. Louis, and C.M. Alberto. 2020. Fenologia e qualidade de frutos de acessos de Physalis spp. Agrarian (Dourados) 13(47):1-8, https://doi. org/10.30612/agrarian.v13i47.8687. 